\title{
EVALUASI PENGGUNAAN OBAT PADA PENDERITA DIARE AKUT PASIEN PEDIATRI DI INSTALASI RAWAT INAP RUMAH SAKIT ADVENT BANDAR LAMPUNG PERIODE JULI - DESEMBER 2019
}

\author{
EVALUTION OF DRUG USE IN ACUTE DIARRHEA PEDIATRIC PATIENTS IN \\ THE INPATIENT INSTALATION AT BANDAR LAMPUNG ADVENTIST \\ HOSPITAL PERIOD JULY - DECEMBER 2019
}

\author{
Subur Widodo ${ }^{1}$, Novita Tri Wahyuni ${ }^{2}$, Lea Yekti Utami ${ }^{3}$ \\ Fakultas MIPA, Program Studi Farmasi Universitas Tulang Bawang Lampung \\ Email : suburwidodo81@ gmail.com \\ HP. 0813-6948-1003
}

\begin{abstract}
Acute diarrhea is diarrhea that lasts less than 14 days. Regarding its severity, acute diarrhea is classified as mild, moderate or severe. Mild when signs of dehydration are not observed, moderate when there are mild or moderate signs of dehydration and rehydration can be done orally and severely when it results in more intense dehydration with or without electrolyte disturbances, and requires intravenous therapy. Diarrhea disease in the Inpatient Installation Bandar Lampung Adventist Hospital is the 10 biggest diseases and has never been evaluated on the use of drugs in pediatric patients. This study aims to evaluate the use of drugs in patients with acute diarrhea inpatients installation at the Bandar Lampung Adventist Hospital calculated from July to December 2019 data. This research is a descriptive study with retrospective data collection. The data collection process begins by tracing medical records of acute diarrhea patients. The population of acute diarrhea cases was 152 patients and then the number of samples obtained was then selected according to the inclusion criteria as a sample of 60 patients. From the research results it is known that the use of drugs in patients with acute diarrhea in pediatric patients includes antibiotics, electrolyte solutions, analgesic/antipyretics, antidiarrheals and other drugs (antihistamines, supplements and probiotics). The validation of drug use on the right indicators, the right patient and the right dose has reached $100 \%$, the right indicator is $37 \%$ and the drug is $63 \%$ incorrect, this is due to the use of antibiotics without laboratory results that show acute diarrhea due to infection.
\end{abstract}

Keywords: acute diarrhea, evaluation of drug use, pediatric 


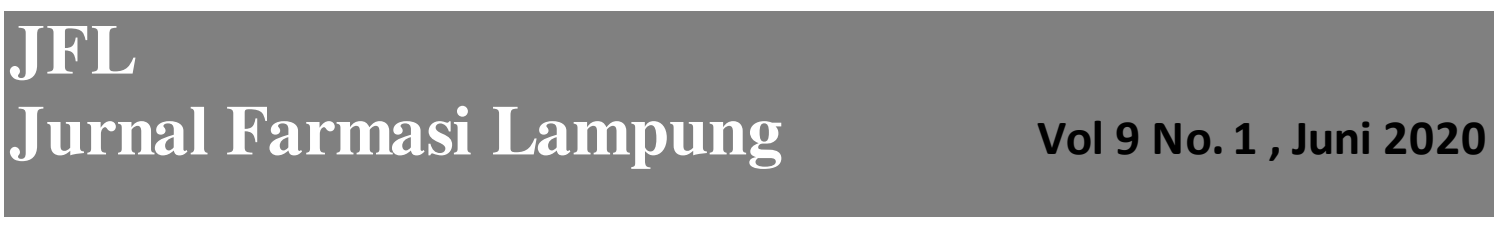

\begin{abstract}
Abstrak
Diare akut adalah diare yang berlangsung kurang dari 14 hari. Mengenai tingkat keparahannya, diare akut diklasifikasikan sebagai ringan, sedang atau berat. Ringan ketika tanda-tanda dehidrasi tidak diamati, sedang ketika ada tanda-tanda ringan atau sedang dehidrasi dan rehidrasi dapat dilakukan secara oral dan berat ketika diare itu menghasilkan dehidrasi yang lebih intens dengan atau tanpa gangguan elektrolit, dan membutuhkan terapi intravena. Penyakit diare di Instalasi Rawat Inap Rumah Sakit Advent Bandar Lampung merupakan 10 penyakit terbesar dan belum pernah dilakukan evaluasi tentang penggunaan obat pada pasien pediatri. Penelitian ini bertujuan untuk mengevaluasi penggunaan obat pada pasien pediatri diare akut di instalasi rawat inap di Rumah Sakit Advent Bandar Lampung terhitung dari data Juli hingga Desember 2019. Penelitian ini merupakan penelitian deskriptif dengan pengambilan data yang dilakukan secara retrospektif. Proses pengumpulan data dimulai dengan melakukan penelusuran data rekam medik pasien diare akut. Populasi kasus diare akut sebanyak 152 pasien kemudian jumlah sampel yang diperoleh kemudian dipilih sesuai kriteria inklusi didapatkan sampel sebanyak 60 pasien. Berdasarkan hasil penelitian ini diketahui penggunaan obat pada penderita diare akut pasien pediatri meliputi antibiotik, larutan elektrolit, analgesik/antipiretik, antidiare dan obat lain - lain (antihistamin, suplemen dan probiotik). Evalusi penggunaan obat pada indikator tepat indikasi, tepat pasien dan tepat dosis telah mencapai $100 \%$, pada indikator tepat obat sebesar $37 \%$ dan tidak tepat obat $63 \%$, hal ini disebabkan penggunaan antibiotik tanpa hasil laboratorium yang memperlihatkan diare akut karena infeksi.
\end{abstract}

Kata Kunci: diare akut, evaluasi penggunaan obat, pediatri.

\section{PENDAHULUAN}

Penyakit diare adalah salah satu penyebab utama kesakitan dan kematian anak di negara-negara berkembang. Sekitar 100 juta kasus terjadi setiap tahun pada balita dengan sekitar 5 juta kematian setiap tahunnya. Penyakit diare merupakan penyakit endemis potensial Kejadian Luar Biasa (KLB) yang sering disertai dengan kematian di Indonesia. Penderita diare secara nasional pada tahun 2018, dengan cakupan tertinggi yaitu Provinsi Nusa Tenggara Barat (75,88\%), DKI Jakarta $(68,54 \%)$ dan Kalimantan Utara $(55,00 \%)$, sedangkan provinsi cakupan terendah yaitu Maluku $(9,77 \%)$, Sumatera Utara $(16,70 \%)$ dan Kepulauan Riau (18,68\%). Profil Kesehatan 2018 menunjukkan penderita diare pada di Propinsi Lampung sebanyak 33,21(1). Penyakit diare merupakan 10 penyakit terbesar di Instalasi Rawat Inap Rumah Sakit Advent Bandar Lampung dan belum pernah dilakukan evaluasi penggunaan obat pada penderita pasien pediatri diare akut.

Diare merupakan suatu kondisi dimana individu mengalami buang air dengan frekuensi sebanyak 3 atau lebih per hari dengan konsistensi tinja dalam bentuk cair. Ini biasanya merupakan gejala infeksi saluran pencernaan. Penyakit ini dapat disebabkan oleh berbagai bakteri, virus dan parasit. Infeksi menyebar melalui makanan atau air minum yang terkontaminasi. Selain itu, dapat terjadi dari orang ke orang sebagai akibat buruknya kebersihan diri (personal hygiene) dan lingkungan (sanitasi). Diare terdiri dari 2 jenis yaitu diare akut 


\section{JFL \\ Jurnal Farmasi Lampung}

dan diare presisten / kronik (2). Diare akut adalah diare yang berlangsung kurang dari 14 hari.

Mengenai tingkat keparahannya, diare akut diklasifikasikan sebagai ringan, sedang atau berat. Ringan ketika tandatanda dehidrasi tidak diamati, sedang ketika ada tanda-tanda ringan atau sedang dehidrasi dan rehidrasi dapat dilakukan secara oral dan berat ketika diare itu menghasilkan dehidrasi yang lebih intens dengan atau tanpa gangguan elektrolit, dan membutuhkan terapi intravena. Sebagian besar kasus diare akut menunjukkan tingkat keparahan ringan atau sedang dan sedang tidak dirawat di layanan kesehatan (3).

Berdasarkan penelitian yang telah dilakukan oleh Sundari Septiani (2015) menunjukkan evaluasi pengobatan diare pada balita dilakukan antara penggunaan antibiotik, zink dan probiotik. Hasil penelitian penggunaan zink, antibiotik dan probiotik pada pasien anak diare di Rumah Sakit X tahun 2014 dapat disimpulkan bahwa analisis kesesuaian zink mengalami tepat indikasi sebanyak $94,20 \%$, tepat pasien sebanyak $94,20 \%$, tepat obat sebanyak $94,20 \%$, tepat dosis sebanyak $76,81 \%$. Pada analisis kesesuaian antibiotik mengalami tepat indikasi sebanyak $43,48 \%$, tepat pasien sebanyak $100 \%$, tepat obat sebanyak $100 \%$, dan tepat dosis sebanyak $4,35 \%$. Sedangkan analisis kesesuaian probiotik mengalami tepat indikasi sebanyak $89,86 \%$, tepat pasien sebanyak $89,86 \%$, tepat obat sebanyak $89,86 \%$ dan tepat dosis sebanyak $14,50 \%(4)$. Penelitian lainnya dilakukan oleh Rifki Amirullah (2015) menunjukkan evaluasi penggunaan obat antidiare pada pasien balita rawat inap di RSUD Karanganyar tahun 2015 dengan parameter tepat indikasi, tepat obat, tepat pasien dan tepat dosis dapat disimpulkan bahwa penggunan obat seperti zink dan lacto-B pada pasien balita diare sudah memenuhi kriteria standar terapi pengobatan yang diberikan oleh dokter. Persentase evaluasi ketepatan indikasi sebesar 100 $\%$, ketepatan obat $100 \%$, ketepatan pasien $100 \%$ dan ketepatan dosis 100 $\%(5)$.

Penyakit diare di Instalasi Rawat Inap Rumah Sakit Advent Bandar Lampung merupakan 10 penyakit terbesar dan belum pernah dilakukan evaluasi penggunaan obat pada penderita diare akut pasien pediatri. Berdasarkan uraian diatas maka peneliti ingin melakukan penelitian tentang Evaluasi Penggunaan Obat Pada Penderita Diare Akut Pasien Pediatri di Instalasi Rawat Inap Rumah Sakit Advent Bandar Lampung periode Juli - Desember 2019.

\section{METODE PENELITIAN}

Penelitian ini termasuk dalam penelitian jenis non-eksperimental dalam penelitian ini tidak ada perlakuan atau intervensi terhadap variable-variabel yang diteliti. Pengambilan data dilakukan secara retropektif dan dianalisis secara deskriptif.

Penentuan jumlah sampel menggunakan rumus (20) :

$$
\mathrm{n}=\frac{\mathrm{N}}{1+\mathrm{N}(\mathrm{d})^{2}}
$$

Keterangan :

$$
\begin{array}{ll}
\mathrm{n} & =\text { Sampel } \\
\mathrm{N} & =\text { Besar Populasi } \\
\mathrm{d} & =\text { Presisi }(0,1)
\end{array}
$$

\section{Lokasi dan Waktu Penelitian}

Penelitian ini dilakukan di Instalasi Rawat Inap Rumah Sakit Advent Bandar Lampung pada periode Juli - Desember 2019. Penelitian ini dilakukan pada bulan Maret - April 2020. 


\section{JFL \\ Jurnal Farmasi Lampung}

\section{Populasi dan Sampel}

Populasi pada penelitian ini adalah semua pasien pediati yang terdiagnosis diare akut di Instalasi Rawat Inap Rumah Sakit Advent Bandar Lampung periode Juli - Desember 2019.

Sampel adalah objek yang diteliti dan dianggap mewakili seluruh populasi. Sampel penelitian ialah sebagian penderita diare akut pasien pediatri di Instalasi Rawat Inap Rumah Sakit Advent Bandar Lampung periode Juli Desember 2019.

\section{HASIL DAN PEMBAHASAN}

\section{Karakteristik Pasien Berdasarkan Jenis Kelamin}

Tabel 4.1 Karakteristik Pasien Berdasarkan Jenis Kelamin

\begin{tabular}{llll}
\hline No & Jenis Kelamin & Jumlah & $\begin{array}{l}\text { Persen } \\
\text { tase }\end{array}$ \\
\hline 1 & Laki - Laki & 37 & $62 \%$ \\
2 & Perempuan & 23 & $38 \%$ \\
\hline \multicolumn{2}{l}{ Total } & 60 & $100 \%$ \\
\hline
\end{tabular}

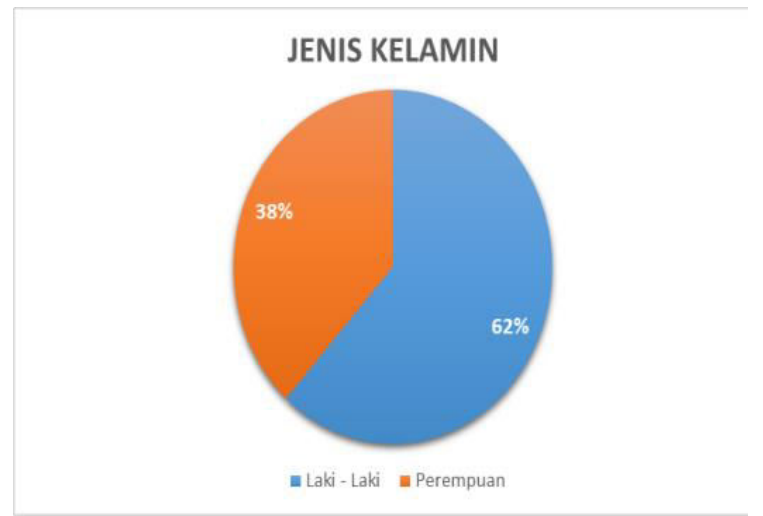

Gambar 4.1 Karakteristik pasien berdasarkan jenis kelamin

Dapat dilihat dari gambar 4.1 bahwa pasien pediatri diare akut di Rumah Sakit Advent Bandar Lampung dengan jenis kelamin laki-laki paling banyak dengan persentase $62 \%$, sedangkan pasien dengan jenis kelamin perempuan sebesar $38 \%$. Hal ini sejalan dengan penelitian sebelumnya yang menunjukkan bahwa penderita diare anak paling banyak pada penelitian ini adalah laki-laki yaitu 96 pasien (56.5\%). Hasil temuan dari studi yang meneliti profil diare dari seluruh negara, dimana dikatakan bahwa laki-laki memiliki kesempatan $9 \%$ lebih besar dibandingkan perempuan untuk menderita diare. Meskipun hasil epidemiologi yang ditemukan selalu konsisten, namun hingga kini belum diketahui alasan dibalik lebih tingginya angka kejadian diare pada anak laki-laki dibandingkan anak perempuan (22).

\section{Karakteristik Pasien Berdasarkan Umur}

Tabel 4.1 Karakteristik Pasien Berdasarkan Umur

\begin{tabular}{llll}
\hline No & Umur & Jumlah & $\begin{array}{l}\text { Persen } \\
\text { tase }\end{array}$ \\
\hline 1 & 2 - 6 Bulan & 11 & $18 \%$ \\
2 & 7 - 11 Bulan & 11 & $18 \%$ \\
3 & 1 - 5 Tahun & 30 & $50 \%$ \\
4 & 6 - 18 Tahun & 8 & $14 \%$ \\
\hline Total & & 60 & $100 \%$ \\
\hline
\end{tabular}

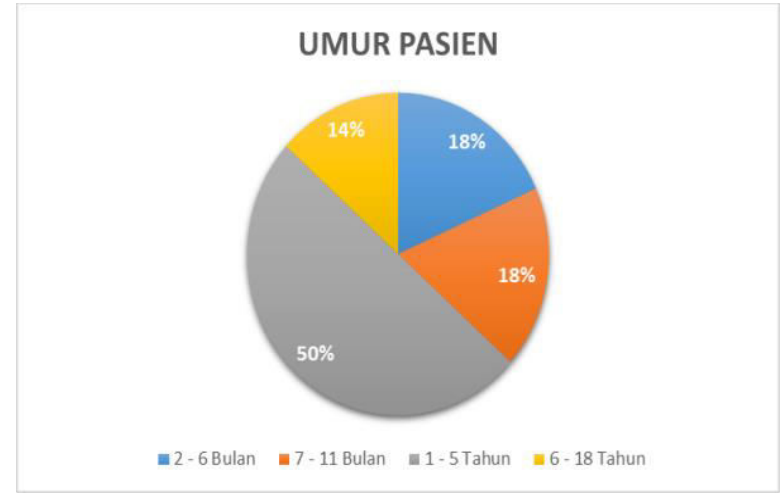

Gambar 4.2 Karakteristik Pasien Berdasarkan Umur 


\section{JFL \\ Jurnal Farmasi Lampung}

Hasil penelitian yang telah dilakukan diketahui karakteristik berdasarkan umur pasien pediatri diare akut di Rumah Sakit Advent Bandar Lampung dengan umur $2-6$ bulan sebanyak 11 pasien, 7 - 11 bulan sebanyak 11 pasien, 1 - 5 tahun sebanyak 30 pasien, dan $6-18$ tahun sebanyak 8 pasien. Kelompok umur diduga disebabkan karena pada anak yang berusia di bawah 2 tahun, kekebalan alaminya belum terbentuk sehingga lebih rentan dalam mengalami infeksi.

\section{Karakteristik Pasien Berdasarkan Lama di Rawat}

Tabel 4.3 Karakteristik Pasien Berdasarkan Lama di Rawat

\begin{tabular}{llll}
\hline No. & $\begin{array}{l}\text { Lama Rawat } \\
\text { Inap }\end{array}$ & $\begin{array}{l}\text { Jum } \\
\text { lah }\end{array}$ & $\begin{array}{l}\text { Persen } \\
\text { tase }\end{array}$ \\
\hline 1 & 1 - 4 Hari & 42 & $70 \%$ \\
2 & 5 - 8 Hari & 18 & $30 \%$ \\
\hline Total & & 60 & $100 \%$ \\
\hline
\end{tabular}

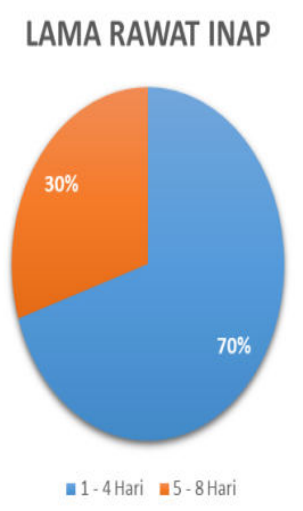

Gambar 4.3 Karakteristik Pasien Berdasarkan Lama Dirawat

Dapat dilihat dari gambar 4.3 bahwa pasien pediatri diare akut di Rumah Sakit Advent Bandar Lampung dengan lama dirawat $1-4$ hari paling banyak dengan persentase $70 \%$, sedangkan pasien dengan lama dirawat $5-8$ hari paling sedikit dengan persentase $30 \%$.
Lama perawatan pasien yang terdiagnosa diare akut adalah 3 - 4 hari dan bersifat mendadak, berlangsung cepat, dan berakhir dalam waktu kurang dari 7 hari. Hal ini dikarenakan karena penyakit diare akut biasanya dapat mengakibatkan dehidrasi yang apabila dapat ditangani dengan cepat maka masa pemulihannyapun akan relatif singkat.

\section{Penggunaan Antibiotik}

Tabel 4.4 Penggunaan Antibiotik

\begin{tabular}{|c|c|c|c|c|}
\hline No. & Nama Obat & $\begin{array}{l}\text { Ju } \\
\mathrm{ml} \\
\text { ah }\end{array}$ & $\begin{array}{l}\text { Pers } \\
\text { enta } \\
\text { se }\end{array}$ & $\begin{array}{l}\text { Golo } \\
\text { ngan }\end{array}$ \\
\hline 1 & Amikasin & 18 & $30 \%$ & $\begin{array}{l}\text { Anti } \\
\text { biotik }\end{array}$ \\
\hline 2 & Cefixime & 6 & $10 \%$ & $\begin{array}{l}\text { Anti } \\
\text { biotik }\end{array}$ \\
\hline 3 & Ceftriaxone & 15 & $25 \%$ & $\begin{array}{l}\text { Anti } \\
\text { biotik }\end{array}$ \\
\hline 4 & Cefadroxil & 1 & $2 \%$ & $\begin{array}{l}\text { Anti } \\
\text { biotik }\end{array}$ \\
\hline 5 & Ciprofloxacn & 1 & $2 \%$ & $\begin{array}{l}\text { Anti } \\
\text { biotik }\end{array}$ \\
\hline 6 & Mikasin & 4 & $7 \%$ & $\begin{array}{l}\text { Anti } \\
\text { biotik }\end{array}$ \\
\hline 7 & Ceftazidime & 1 & $2 \%$ & $\begin{array}{l}\text { Anti } \\
\text { biotik }\end{array}$ \\
\hline 8 & Ceptik & 7 & $12 \%$ & $\begin{array}{l}\text { Anti } \\
\text { biotik }\end{array}$ \\
\hline 9 & Nifural & 2 & $3 \%$ & $\begin{array}{l}\text { Anti } \\
\text { biotik }\end{array}$ \\
\hline 10 & Starxon & 4 & $7 \%$ & $\begin{array}{l}\text { Antibioti } \\
\mathrm{k}\end{array}$ \\
\hline 11 & Taxegram & 1 & $2 \%$ & $\begin{array}{l}\text { Antibioti } \\
\mathrm{k}\end{array}$ \\
\hline 12 & Terfacef & 2 & $3 \%$ & $\begin{array}{l}\text { Anti } \\
\text { biotik }\end{array}$ \\
\hline 13 & Trichodazole & 3 & $5 \%$ & $\begin{array}{l}\text { Anti } \\
\text { biotik }\end{array}$ \\
\hline 14 & Promuba & 1 & $2 \%$ & $\begin{array}{l}\text { Anti } \\
\text { biotik }\end{array}$ \\
\hline 15 & Nifudiar & 1 & $2 \%$ & $\begin{array}{l}\text { Anti } \\
\text { biotik }\end{array}$ \\
\hline
\end{tabular}

Penggunaan antibiotik pasien pediatri diare akut di Rumah Sakit Advent 


\section{JFL \\ Jurnal Farmasi Lampung}

Bandar Lampung menggunakan amikasin $30 \%$ dengan persentase dan ceftriaxone dengan persentase $25 \%$. Penggunaan antibiotik hanya diberikan jika ada indikasi infeksi, seperti diare berdarah atau diare karena kolera, atau diare dengan disertai penyakit lain. Sedangkan pada kasus diare tanpa infeksi tidak memerlukan antibiotik. Ini sangat penting karena seringkali ketika diare, masyarakat langsung membeli antibiotik seperti tetrasiklin atau ampicillin. Selain tidak efektif, tindakan ini berbahaya, karena jika antibiotik tidak dihabiskan sesuai dosis akan menimbulkan resistensi kuman terhadap antibiotik (13). Berdasarkan penelitian pada journal de pediatria, antibiotik yang tidak memadai untuk pengobatan shigellosis pada diare akut adalah ampisilin, kloramfenikol, gentamisin amoksisilin (24).

\section{Penggunaan Cairan Elektrolit}

Tabel 4.5 Penggunaan Cairan Elektrolit

\begin{tabular}{lllll}
\hline $\begin{array}{l}\mathrm{N} \\
\text { o. }\end{array}$ & $\begin{array}{l}\text { Nama } \\
\text { Obat }\end{array}$ & $\begin{array}{l}\text { Jum } \\
\text { lah }\end{array}$ & $\begin{array}{l}\text { Perse } \\
\text { ntase }\end{array}$ & $\begin{array}{l}\text { Golo } \\
\text { ngan }\end{array}$ \\
\hline 1 & KA-EN 3B & 30 & $50 \%$ & $\begin{array}{l}\text { Elek } \\
\text { trolit }\end{array}$ \\
& $\begin{array}{l}\text { Ringer } \\
\text { Lactat (RL) }\end{array}$ & 50 & $83 \%$ & Elek \\
trolit
\end{tabular}

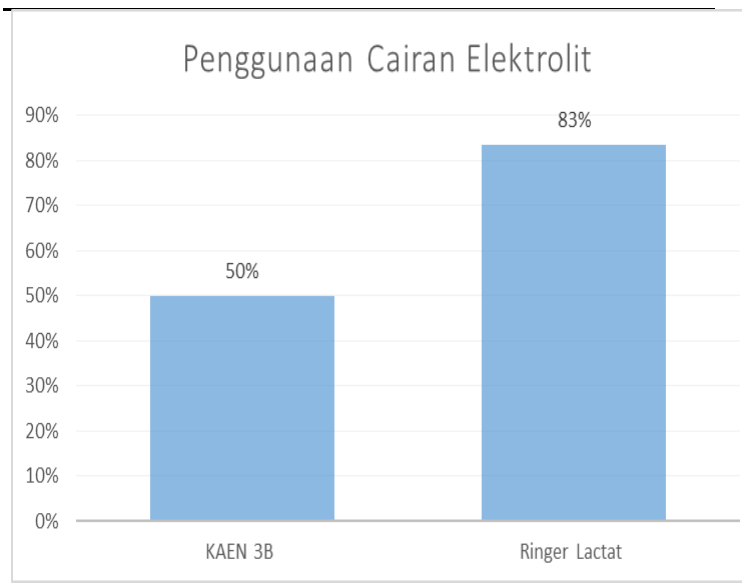

Gambar 4.5 Penggunaan Cairan Elektrolit
Hasil penelitian yang telah dilakukan diketahui penggunaan cairan elektrolit pasien pediatri diare akut di Rumah Sakit Advent Bandar Lampung menggunakan $\mathrm{RL}$ dengan persentase 83\% dan KA-EN 3B dengan persentase $50 \%$. Terapi cairan adalah salah satu terapi yang sangat menentukan keberhasilan penanganan pasien kritis. Dalam langkah-langkah resusitasi, langkah D ("drug and fluid treatment") dalam bantuan hidup lanjut, merupakan langkah penting yang dilakukan secara simultan dengan langkah-langkah lainnya. Tindakan ini seringkali merupakan langkah "life saving" pada pasien yang menderita kehilangan cairan yang banyak seperti dehidrasi karena muntah mencret dan syok (25). Penderita diare akut dengan dehidrasi berat harus diberi rehidrasi intravena secara cepat yang diikuti dengan terapi rehidrasi oral.

Hal ini sejalan dengan penelitian sebelumnya yang menunjukkan bahwa sebagian besar pasien diare akut di Rumah Sakit Islam Kendal diberikan cairan RL sebanyak 55 responden $(91,7 \%)$. RL merupakan larutan infus untuk memelihara keseimbangan atau mengganti elektrolit dan cairan tubuh (26). 
Jurnal Farmasi Lampung

\section{Penggunaan Obat Saluran \\ Pencernaan}

Tabel 4.6 Penggunaan Obat Saluran Pencernaan

\begin{tabular}{|c|c|c|c|c|}
\hline $\begin{array}{l}\mathrm{N} \\
\mathrm{O}\end{array}$ & $\begin{array}{l}\text { Nama } \\
\text { Obat }\end{array}$ & $\begin{array}{l}\mathrm{J} \\
\mathrm{u} \\
\mathrm{m} \\
\mathrm{l} \\
\mathrm{a} \\
\mathrm{h}\end{array}$ & $\begin{array}{l}\text { Persen } \\
\text { tase }\end{array}$ & Golongan \\
\hline 1 & $\begin{array}{l}\text { Ome } \\
\text { prazole }\end{array}$ & 5 & $8 \%$ & $\begin{array}{l}\text { Penghambat } \\
\text { Pompa } \\
\text { Proton }\end{array}$ \\
\hline 2 & $\begin{array}{l}\text { Ondan } \\
\text { setron }\end{array}$ & $\begin{array}{l}2 \\
5\end{array}$ & $42 \%$ & Antiemetik \\
\hline 3 & Sotatic & 1 & $2 \%$ & Antiemetik \\
\hline 4 & $\begin{array}{l}\text { Dom } \\
\text { peridon }\end{array}$ & 4 & $7 \%$ & Antiemetik \\
\hline 5 & Invomit & 9 & $15 \%$ & Antiemetik \\
\hline 6 & Inpepsa & 1 & $2 \%$ & Antiulcerant \\
\hline 7 & $\begin{array}{l}\text { Rani } \\
\text { tidin }\end{array}$ & 2 & $3 \%$ & $\begin{array}{l}\text { Antagonis } \\
\text { Reseptor-H2 }\end{array}$ \\
\hline 8 & $\begin{array}{l}\text { Cime } \\
\text { tidine }\end{array}$ & 1 & $2 \%$ & $\begin{array}{l}\text { Antagonis } \\
\text { Reseptor-H2 }\end{array}$ \\
\hline
\end{tabular}

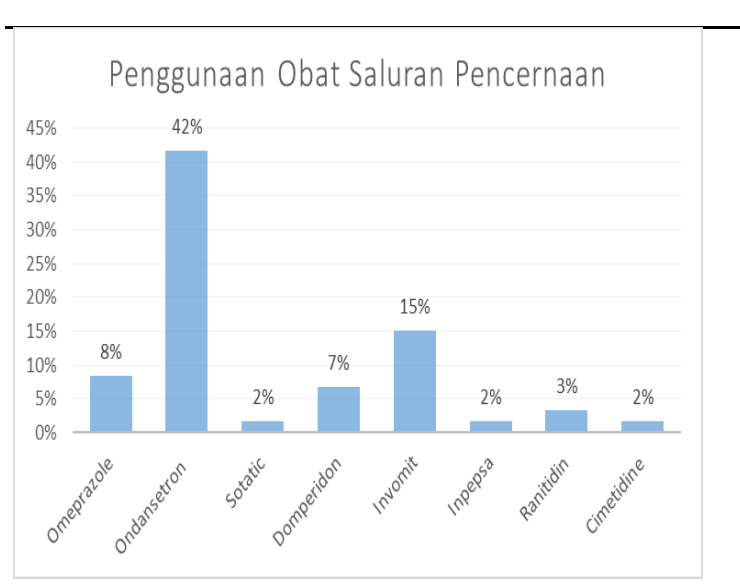

Gambar 4.6 Penggunaan Obat Saluran Pencernaan Penderita Diare Akut
Hasil penelitian yang telah dilakukan diketahui penggunaan obat saluran pencernaan pasien pediatri diare akut di Rumah Sakit Advent Bandar Lampung menggunakan ondansetron dengan persentase $42 \%$ dan invomit dengan persentase $\quad 15 \%$. Penggunaan ondansentron sebagai antiemetik pada pasien diare akut merupakan suatu pilihan yang sudah tepat. Pada mulanya odansentron merupakan obat antiemetik untuk mengurangi efek mual dan muntah yang ditimbulkan akibat radiasi dengan efek samping yang paling ringan. Namun, penelitian terbaru menunjukkan bahwa ondansentron juga dapat menurunkan frekuensi diare dan mengurangi efek mual dan muntah pada pasien diare (27).

\section{Penggunaan Obat Diare}

Tabel 4.7 Penggunaan Obat Diare

\begin{tabular}{lllll}
\hline $\begin{array}{l}\text { N } \\
\text { o. }\end{array}$ & $\begin{array}{l}\text { Nama } \\
\text { Obat }\end{array}$ & $\begin{array}{l}\text { Jum } \\
\text { lah }\end{array}$ & $\begin{array}{l}\text { Persen } \\
\text { tase }\end{array}$ & $\begin{array}{l}\text { Golon } \\
\text { gan }\end{array}$ \\
\hline 1 & Lodia & 2 & $3 \%$ & $\begin{array}{l}\text { Anti } \\
\text { diare } \\
\text { Anti }\end{array}$ \\
& Smecta & 41 & $68 \%$ & $\begin{array}{l}\text { diare } \\
\text { Anti } \\
\text { diare }\end{array}$ \\
& Arcapec & 1 & $2 \%$ &
\end{tabular}

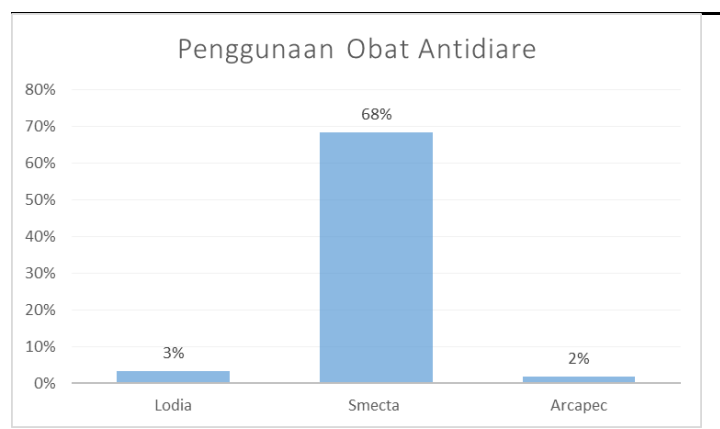

Gambar 4.7 Penggunaan Obat Antidiare Penderita Diare Akut

Hasil penelitian yang telah dilakukan diketahui penggunaan obat antidiare 
pasien pediatri diare akut di Rumah Sakit Advent Bandar Lampung menggunakan smecta dengan persentase $68 \%$. Smecta adalah obat anti diare dalam bentuk serbuk (powder) yang mengandung komposisi dioctahedral smectite yang merupakan adsorben yang efektif dan telah dipakai secara meluas dalam pengobatan diare pada anak. Pemberian dioctahedral smectite dapat memperpendek durasi diare pada anak(28).

\section{Penggunaan Obat Analgesik atau Antipiretik}

Tabel 4.8 Penggunaan Obat Analgetik atau Antipiretik

\begin{tabular}{|c|c|c|c|c|}
\hline $\begin{array}{l}\mathrm{N} \\
\mathrm{O} .\end{array}$ & $\begin{array}{l}\text { Nama } \\
\text { Obat }\end{array}$ & $\begin{array}{l}\text { Jum } \\
\text { lah }\end{array}$ & $\begin{array}{l}\text { Persen } \\
\text { tase }\end{array}$ & $\begin{array}{l}\text { Golo } \\
\text { ngan }\end{array}$ \\
\hline 1 & $\begin{array}{l}\text { Bus } \\
\text { copan }\end{array}$ & 1 & $2 \%$ & $\begin{array}{l}\text { Anal } \\
\text { gesik }\end{array}$ \\
\hline 2 & $\begin{array}{l}\text { Para } \\
\text { setamol }\end{array}$ & 36 & $60 \%$ & $\begin{array}{l}\text { Anal } \\
\text { gesik } \\
\text { Anti } \\
\text { piretik }\end{array}$ \\
\hline 3 & $\begin{array}{l}\text { San } \\
\text { mol }\end{array}$ & 9 & $15 \%$ & $\begin{array}{l}\text { Anal } \\
\text { gesik } \\
\text { Anti } \\
\text { piretik }\end{array}$ \\
\hline 4 & $\begin{array}{l}\text { Nap } \\
\text { rex }\end{array}$ & 2 & $3 \%$ & $\begin{array}{l}\text { Anal } \\
\text { gesik } \\
\text { Anti } \\
\text { piretik }\end{array}$ \\
\hline
\end{tabular}

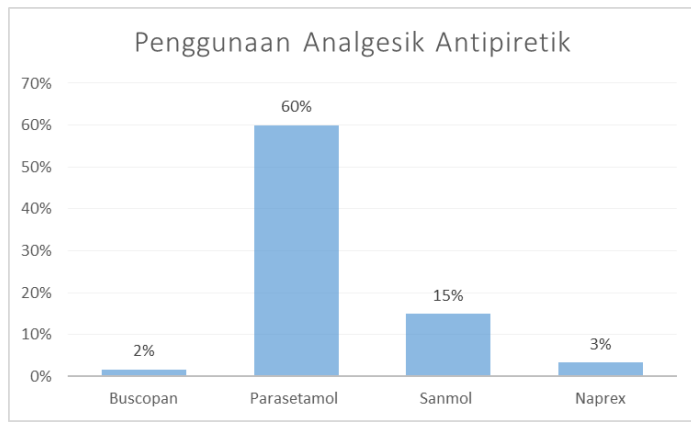

Gambar 4.8 Penggunaan obat Analgesik/Antipiretik Penderita Diare Akut

Hasil penelitian yang telah dilakukan diketahui penggunaan obat analgesik / antipiretik pasien pediatri diare akut di Rumah Sakit Advent Bandar Lampung menggunakan paracetamol dengan persentase $60 \%$ dan sanmol dengan persentase $15 \%$. Jenis antipiretik yang digunakan dalam penelitian ini adalah parasetamol. Selain berfungsi sebagai antipiretik, parasetamol juga berfungsi sebagai analgesik. Antipiretik merupakan obat yang digunakan untuk menurunkan demam yang ditandai oleh peningkatan suhu tubuh pasien. Gejala demam pada penderita diare akut anak umum terjadi dan biasa disebabkan oleh aktivitas invasif pathogen (29). Hal ini sejalan dengan penelitian sebelumnya yang menunjukkan penggunaan antipiretik dalam penelitiannya sebanyak 25 pasien $(54,35 \%)$.

\section{Penggunaan Obat - Obat Lain}

Tabel 4.9 Penggunaan Obat - Obat Lain

\begin{tabular}{lllll}
\hline $\begin{array}{l}\mathrm{N} \\
\mathrm{O} .\end{array}$ & $\begin{array}{l}\text { Nama } \\
\text { Obat }\end{array}$ & $\begin{array}{l}\text { Jum } \\
\text { lah }\end{array}$ & $\begin{array}{l}\text { Persn } \\
\text { tase }\end{array}$ & $\begin{array}{l}\text { Golo } \\
\text { ngan }\end{array}$ \\
\hline 1 & $\begin{array}{l}\text { Beta } \\
\text { histin }\end{array}$ & 1 & $2 \%$ & $\begin{array}{l}\text { Antihis } \\
\text { tamin }\end{array}$ \\
2 & Interlac & 8 & $13 \%$ & Probio \\
tik
\end{tabular}




\section{JFL \\ Jurnal Farmasi Lampung}

\begin{tabular}{|c|c|c|c|c|}
\hline 3 & Lacbon & 24 & $40 \%$ & $\begin{array}{l}\text { Probio } \\
\text { tik }\end{array}$ \\
\hline 4 & $\begin{array}{l}\text { Lipro } \\
\text { lac }\end{array}$ & 1 & $2 \%$ & $\begin{array}{l}\text { Probio } \\
\text { tik }\end{array}$ \\
\hline 5 & $\begin{array}{l}\text { Probio } \\
\text { kid }\end{array}$ & 2 & $3 \%$ & $\begin{array}{l}\text { Probio } \\
\text { tik }\end{array}$ \\
\hline 6 & $\begin{array}{l}\text { Coba } \\
\text { zim }\end{array}$ & 1 & $2 \%$ & $\begin{array}{l}\text { Sup } \\
\text { lemen }\end{array}$ \\
\hline 7 & Metavit & 2 & $3 \%$ & $\begin{array}{l}\text { Sup } \\
\text { lemen }\end{array}$ \\
\hline 8 & $\begin{array}{l}\text { Inter } \\
\text { zinc }\end{array}$ & 6 & $10 \%$ & $\begin{array}{l}\text { Sup } \\
\text { lemen }\end{array}$ \\
\hline 9 & Zink & 21 & $35 \%$ & $\begin{array}{l}\text { Sup } \\
\text { lemen }\end{array}$ \\
\hline
\end{tabular}

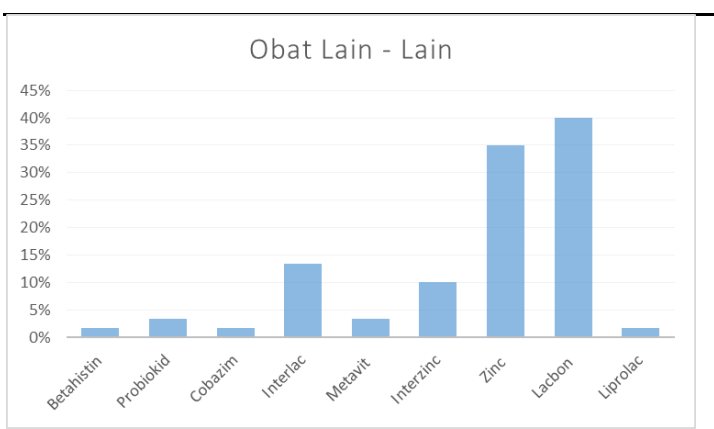

Gambar 4.9 Penggunaan Obat Lain lain Penderita Diare Akut

Hasil penelitian yang telah dilakukan diketahui penggunaan obat lain - lain pasien pediatri diare akut di Rumah Sakit Advent Bandar Lampung berupa lacbon dengan persentase $40 \%$ dan zink dengan persentase $35 \%$. Penggunaan zink pada diare akut merupakan salah satu zat gizi mikro yang penting untuk kesehatan dan pertumbuhan anak. Mineral zink yang ada dalam tubuh akan menurun dalam jumlah besar ketika anak mengalami diare. Pemberian suplemen mampu menggantikan kandungan zink alami tubuh yang hilang tersebut dan mempercepat penyembuhan diare.
Suplemen juga meningkatkan sistem kekebalan tubuh sehingga dapat mencegah risiko terulangnya diare selama 2-3 bulan setelah anak sembuh dari diare (13).

Pemberian probiotik pada pasien diare akut merupakan terapi yang tepat sebab telah dibuktikan melalui penelitian bahwa probiotik efektif untuk pencegahan dan pengobatan terhadap berbagai kelainan gastrointestinal, misalnya diare yang disebabkan oleh pemakaian antibiotik yang berlebihan, infeksi bakteri maupun virus, intoleransi laktosa dan traveller diarrhea. Peningkatan jumlah probiotik di saluran cerna akan memiliki efek yang positif karena berkompetisi untuk nutrisi dan reseptor dalam saluran cerna. Probiotik juga mempunyai keuntungan dalam terapi penyakit diare pada anak melalui stimulasi sistem imunitas terutama infeksi rotavirus pada bayi, dimana suplementasi probiotik mengurangi durasi penyebaran virus, meningkatkan sel yang mensekresi lgA antirotavirus, menurunkan peningkatan permeabilitas usus (yang secara normal berhubungan dengan infeksi rotavirus) dan mengurangi durasi diare dan lama rawat rumah sakit (30).

\section{Evaluasi Penggunaan Indikasi}

Tabel 4.10 Evaluasi Penggunaan Indikasi

\begin{tabular}{lll}
\hline Evaluasi & $\begin{array}{l}\text { Jumlah } \\
\text { Kasus }\end{array}$ & $\begin{array}{l}\text { Persen } \\
\text { tase }\end{array}$ \\
\hline $\begin{array}{l}\text { Tepat } \\
\text { Indikasi }\end{array}$ & 60 & $100 \%$ \\
$\begin{array}{l}\text { Tidak Tepat } \\
\text { Indikasi }\end{array}$ & 0 & $0 \%$ \\
\hline
\end{tabular}

Hasil penelitian yang telah dilakukan menunjukan bahwa evaluasi tepat indikasi penderita diare akut pasien pediatri di Instalasi Rawat Inap Rumah 
Sakit Advent Bandar Lampung periode Juli - Desember 2019 mendapatkan hasil tepat indikasi berdasarkan adanya pemeriksaan fisik dan hasil laboratorium sebanyak 60 kasus dengan persentase $100 \%$.

Tabel 4.11 Diagnosa Penderita Diare Akut Pasien Pediatri

\begin{tabular}{|c|c|c|c|}
\hline $\begin{array}{l}N \\
\mathrm{O}\end{array}$ & Diagnosa & $\begin{array}{l}\text { Jum } \\
\text { lah }\end{array}$ & $\begin{array}{l}\text { Persen } \\
\text { tase }\end{array}$ \\
\hline 1 & GEA & 4 & $7 \%$ \\
\hline 2 & $\begin{array}{l}\text { GEA + bacterial } \\
\text { infection }\end{array}$ & 3 & $5 \%$ \\
\hline 3 & $\begin{array}{l}\text { GEA + } \\
\text { leukositosis }\end{array}$ & 1 & $2 \%$ \\
\hline 4 & $\begin{array}{l}\text { GEA dehidrasi } \\
\text { ringan }\end{array}$ & 2 & $3 \%$ \\
\hline 5 & $\begin{array}{l}\text { GEA dehidrasi } \\
\text { ringan + bacterial } \\
\text { infection }\end{array}$ & 1 & $2 \%$ \\
\hline 6 & $\begin{array}{l}\text { GEA dehidrasi } \\
\text { ringan + obs.febris }\end{array}$ & 1 & $2 \%$ \\
\hline 7 & $\begin{array}{l}\text { GEA dehidrasi } \\
\text { ringan-sedang }\end{array}$ & 3 & $5 \%$ \\
\hline 8 & $\begin{array}{l}\text { GEA dehidrasi } \\
\text { ringan-sedang + } \\
\text { bacterial infection }\end{array}$ & 1 & $2 \%$ \\
\hline 9 & $\begin{array}{l}\text { GEA dehidrasi } \\
\text { sedang }\end{array}$ & 32 & $53 \%$ \\
\hline 10 & $\begin{array}{l}\text { GEA dehidrasi } \\
\text { sedang + bacterial } \\
\text { infection }\end{array}$ & 5 & $8 \%$ \\
\hline 11 & $\begin{array}{l}\text { GEA dehidrasi } \\
\text { sedang + } \\
\text { hiperpireksia }\end{array}$ & 1 & $2 \%$ \\
\hline 12 & $\begin{array}{l}\text { GEA dehidrasi } \\
\text { sedang + } \\
\text { hiperpireksia + } \\
\text { leukositosis }\end{array}$ & 1 & $2 \%$ \\
\hline 13 & GEA dehidrasi & 3 & $5 \%$ \\
\hline
\end{tabular}

sedang +

obs.febris

14

GEA dehidrasi sedang-berat

$12 \%$

15

GEA intolerance lactosa

\begin{tabular}{lll}
\hline Total & 60 & $100 \%$ \\
\hline
\end{tabular}

Diketahui diagnosa paling banyak yaitu GEA dengan dehidrasi sedang dengan jumlah 32 kasus dengan persentase $53 \%$. Diare dehidrasi ringan atau sedang bila terdapat dua tanda atau lebih, antara lain gelisah, rewel dan mata cekung, ingin minum terus, ada rasa haus dan cubitan kulit perut atau turgor kembali lambat (13).

Tabel 4.12 Evaluasi Tepat Pasien

\begin{tabular}{lll}
\hline Evaluasi & $\begin{array}{l}\text { Jumlah } \\
\text { Kasus }\end{array}$ & $\begin{array}{l}\text { Persen } \\
\text { tase }\end{array}$ \\
\hline Tepat Pasien & 60 & $100 \%$ \\
$\begin{array}{l}\text { Tidak Tepat } \\
\text { Pasien }\end{array}$ & 0 & $0 \%$ \\
\hline
\end{tabular}

Hasil penelitian yang telah dilakukan menunjukan bahwa evaluasi tepat pasien penderita diare akut pasien pediatri di Instalasi Rawat Inap Rumah Sakit Advent Bandar Lampung periode Juli - Desember 2019 mendapatkan hasil tepat pasien dengan persentase $100 \%$.

Tabel 4.13 Evaluasi Tepat Obat

\begin{tabular}{lll}
\hline Evaluasi & $\begin{array}{l}\text { Jumlah } \\
\text { Kasus }\end{array}$ & $\begin{array}{l}\text { Persen } \\
\text { tase }\end{array}$ \\
\hline Tepat Obat & 22 & $37 \%$ \\
$\begin{array}{l}\text { Tidak Tepat } \\
\text { Obat }\end{array}$ & 38 & $63 \%$ \\
\hline
\end{tabular}




\section{JFL \\ Jurnal Farmasi Lampung}

Hasil penelitian yang telah dilakukan menunjukan bahwa evaluasi tepat obat penderita diare akut pasien pediatri di Instalasi Rawat Inap Rumah Sakit Advent Bandar Lampung periode Juli Desember 2019 mendapatkan hasil tepat obat dengan persentase $37 \%$ dan tidak tepat obat $63 \%$. Pada 38 kasus dengan persentase $63 \%$ tidak tepat obat, dikarenakan adanya penggunaan antibiotik tanpa hasil laboratorium yang memperlihatkan diare akut karena infeksi. Hal ini akan mengakibatkan pemberian obat tanpa indikasi.

Tabel 4.14 Evaluasi Tepat Dosis

\begin{tabular}{lll}
\hline Evaluasi & $\begin{array}{l}\text { Jumlah } \\
\text { Kasus }\end{array}$ & $\begin{array}{l}\text { Persen } \\
\text { tase }\end{array}$ \\
\hline $\begin{array}{l}\text { Tepat Dosis } \\
\text { Tidak Tepat } \\
\text { Dosis }\end{array}$ & 60 & $100 \%$ \\
\hline
\end{tabular}

Hasil penelitian yang telah dilakukan menunjukan bahwa evaluasi tepat dosis penderita diare akut pasien pediatri di Instalasi Rawat Inap Rumah Sakit Advent Bandar Lampung periode Juli Desember 2019 mendapatkan hasil tepat dosis dengan persentase $100 \%$.

\section{SIMPULAN DAN SARAN}

\section{Simpulan}

Dari hasil penelitan evaluasi penggunaan obat pada penderita diare akut pasien pediatri di Instalasi Rawat Inap Rumah Sakit Advent Bandar Lampung periode Juli - Desember 2019 dapat disimpulkan bahwa:

1. Karakteristik penderita diare akut pasien pediatri dengan jenis kelamin laki -laki sebesar $62 \%$ dan perempuan sebesar $38 \%$, umur pasien 2-6 bulan sebesar $18 \%, 7-11$ bulan sebesar $18 \%, 1-5$ tahun sebesar 50\%, 6-18 tahun sebesar
$14 \%$, lama dirawat $1-4$ hari sebesar $70 \%$ dan $5-8$ hari sebesar $30 \%$.

2. Evalusi penggunaan obat berdasarkan pada indikator tepat indikasi, tepat pasien dan tepat dosis telah mencapai $100 \%$ tepat, pada indikator tepat obat sebesar $37 \%$ dan tidak tepat obat $63 \%$, hal ini disebabkan penggunaan antibiotik tanpa hasil laboratorium yang memperlihatkan diare akut karena infeksi.

3. Penggunaan obat pada penderita diare akut pasien pediatri meliputi antibiotik, larutan elektrolit, analgesik/antipiretik, antidiare dan obat lain-lain (antihistamin, suplemen dan probiotik).

\section{Saran}

Berdasarkan kesimpulan diatas, peneliti memberi saran sebagai berikut:

1. Bagi pihak Rumah Sakit Advent Bandar Lampung diharapkan penelitian ini dapat dijadikan gambaran dalam pemberian terapi pengobatan diare akut sehingga kedepannya lebih baik.

2. Bagi peneliti selanjutnya dapat melakukan penelitian tentang DRP's pada penderita diare akut pasien pediatri di Instalasi Rawat Inap Rumah Sakit Advent Bandar Lampung.

\section{UCAPAN TERIMAKASIH}

Terimakasih kepada seluruh pihak Universitas Tulang Bawang Lampung dan Rumah Sakit Advent Bandar Lampung yang telah membantu dalam menyelesaikan penelitian.

\section{DAFTAR PUSTAKA}

1. Kementrian Kesehatan Republik Indonesia. 2019. Data dan Informasi Profil Kesehatan Indonesia 2018. Jakarta: Kementrian Kesehatan Rl; 
2. Okafriani. 2017. Diare Balita: Suatu Tinjauan dari Bidang Kesehatan Masyarakat. Yogyakarta: Deepublish;

3. Kátia Galeão Brandt. 2015. Acute diarrhea: evidence-based management. J Pediatri. 91(S36):43.

4. Sundari Septiani. 2015. Evaluasi Penggunaan Obat Pada Pasien Balita Terkena Diare Pada Pasien Rawat Inap Di Rumah Sakit X Tahun 2014. Fak Farm Univ Muhammadiyah Surakarta.

5. Amirullah R 2015. Evaluasi Penggunaan Obat Antidiare Pada Pasien Balita Rawat Inap Di Rumah Sakit Umum Daerah Karanganyar Tahun 2015. Progr Stud D-III Farm Fak Farm Univ Setia Budi Surakarta.

6. Menteri Kesehatan Republik Indonesia.2014. PERMENKES RI No. 56 Tahun 2014 Tentang Klasifikasi Dan Perizinan Rumah Sakit.

7. Menteri Kesehatan Republik Indonesia. 2019. Peraturan Menteri Kesehatan Republik Indonesia Nomor 30 Tahun 2019 Tentang Klasifikasi Dan Perizinan Rumah Sakit. Jakarta: Kementeri Kesehatan Republik Indonesia;

8. Sodikin.2011. Asuhan Keperawatan Anak Gangguan Sistem Gastrointestinal. Jakarta: Salemba Medika; 25-26 p.

9. DiPiro. 2017. Pharmacotherapy: A Pathophysiologic Approach. 10 edition. United States of America: McGraw-Hill Education;

10. Soegeng Soegijanto. 2016. Kumpulan Makalah Penyakit Tropis dan Infeksi di Indonesia Jilid 7. Airlangga University Press;

11. Riddle. 2016. ACG Clinical Guideline: Diagnosis, Treatment, and Prevention of Acute Diarrheal Infections in Adults. Am J Gastroenterol.

12. Maxine A. 2019. Current Medical Diagnosis \& Treatment Fifty-Eighth Edition. McGraw-Hill Education;
13. Direktorat Jenderal Pengendalian Penyakit dan Penyehatan Lingkungan. Buku Saku Petugas Kesehatan. 2011. Jakarta: Departemen Kesehatan RI;

14. Rina Agustina. 2012. Probiotics, calcium and acute diarrhea. The Netherlands: Thesis Wageningen University;

15. Derektorat Bina Farmasi Komunitas dan Klinik. 2009. Pedoman Pelayanan Kefarmasian Untuk Pasien Pediatri. Jakarta: Departemen Kesehatan Rl;

16. Irmawati Mathar. 2018. Manajemen Informasi Kesehatan Pengelolaan Dokumen Reicam Medis. Yogyakarta: Deepublish;

17. Setya Enti Rokhimah. 2017. Farmasi Rumah Sakit. Yogyakarta: Deepublish;

18. Kementrian Kesehatan Republik Indonesia. 2011. Modul Penggunaan Obat Rasional. Jakarta: Kementrian Kesehatan Republik Indonesia;

19. Kementrian Kesehatan Republik Indonesia. 2016. Tentang Standar Pelayanan Kefarmasian Di Rumah Sakit. Jakarta: Kemenkes Rl;

20. Notoatmodjo S. 2012. Metodologi Penelitian Kesehatan. Jakarta: Rineka Cipta;

21. Alfan Padilah. 2017. Karakteristik Penderita Diare Akut dengan Dehidrasi pada Anak. Pros Pendidik Dr Univ Islam Bandung.

22. Dewa Made Satrianjaya. 2019. Karakteristik diare pada anak di RSUP Sanglah Denpasar tahun 2017. Orig Artic Intisari Sains Medis.

23. Ayu Selvia. 2019. Karakteristik Penderitadiare Pada Balita Yang Dirawat Inap Di Rsud Daya Kota Makassar Periode Januari Desember 2016. Skripsi Progr Stud Pendidik Dr Univ Hasanuddin.

24. Mara Alves da Cruz Gouveia. 2019. Acute diarrhea with blood: diagnosis and drug treatment. J Pediatr.

25. Stoelting RK. 2015. Handbook of Pharmacology and Physiology in 
Anesthetic Practice 3rd: Intravenous Fluids and Electrolytes. Philadelphia: Wolters Kluwer Health;

26. Ridaul Chasanah. 2018. Resusitasi Cairan Pada Anak Diare Dengan Dehidrasi Di Rumah Sakit Islam Kendal. Skripsi Univ Muhammadiyah Semarang.

27. Kiesewetter. 2013. Ondansetron for Diarrhea Associated with Neuroendocrine Tumors. N Engl J Med.

28. Satrio Wibowo. 2018. Dioctahedral Smectite Memperpendek Durasi Diare Kronik Pada Anak. J Kesehat Univ Brawijaya.

29. Arifani Siswidiasari. 2018. Profil Terapi Obat Pada Pasien Rawat Inap Dengan Diare Akut Pada Anak Di Rumah Sakit Umum Negara. J Kim Univ Udayana.
30. Waspada. 2012. Suplementasi Probiotik pada Terapi Standar Zinc dan Cairan Rehidrasi Oral pada Anak Usia 6-36 Bulan dengan Diare Akut. Tesis Univ Indones.

31. Eko Sarwono. 2018. Valuasi Penggunaan Obatpada Pasien Balita Diare Akut di Instalasi Rawat Inap Rumah Sakit Islamklaten Tahun 2017. Fak Farm Univ Setia Budi Surakarta.

32. Aprila Nurul Lailana. 2018. Evaluasi Penggunaan Obat Diare Pada Pasien Anak Di Instalasi Rawat Inap Rsud Panembahan Senopati Bantul Periode 2016. Progr Stud Farm Kedokt Dan IImu Kesehatan Universitas Yogyakarta. 